\title{
Impact of Market, Environment and Governing System on Agriculture and Milk Production in Punjab
}

\author{
Nirwan $^{1^{*}}$ and Prakash Mahto ${ }^{2}$ \\ ${ }^{1}$ Department of Planning, School of Planning and Architecture, Vijayawada, India \\ ${ }^{2}$ Department of Urban Planning, Lovely School of Architecture and Design, India \\ *Corresponding author
}

\section{Keywords}

Food Sustainability,

Agriculture

Sustainability,

Crop

Diversification,

Milk Production,

Farming Practices

Article Info

Accepted:

12 June 2021

Available Online:

10 July 2021

\section{A B S T R A C T}

Higher consumption of resources can be seen as a prerequisite to development and urban sprawl in growing countries. Many attempts have been made in order to reduce the exploitation and prevent the exhaustion of natural resources. A similar attempt has been made by the Punjab administration in India that has huge contribution to the food production system of the country. In order to safeguard the depleting ground water and increasing financial strain on the poor farmers, the Punjab Government has diverted its future to agriculture diversification. Since the growth pattern is highly directed by the market demands the approach may raise questions on the food sustainability of the nation. This phenomenon is not limited to agriculture but is also affecting the quality of milk production in the state. Realizing the potential shift in the agricultural pattern and the increasing losses in the food production, this paper tries to detail out the factors leading to existing agricultural and milk production activities and how the existing interventions may affect the future of Punjab. We have referred multiple articles and papers in order to develop a more sustainable and synergic approach to the system, in order to protect the quantity and quality of food produced in the upcoming years of Punjab.

\section{Introduction}

Food being an important resource has been shaping the civilization from its inception; evolving the way of life itself. Consequently, there was a paradigm shift to agricultural activities, by providing the people with a more reliable source of food. Over the decades, land became the primary resource for agricultural practices and gained significant importance as a factor of production. Moreover, the technique of mixed farming was evolved to cater to their nutritional demand from the parcel of land. Furthermore, the surplus became a way for them to extract investment and realize profits. The population explosion has led to increased demand for food in the market which resulted in an inclination of 
farmers' preference towards yielding more profits. The concept of subsistence farming subsided. In the same manner, trade got amplified through newly established and accessible markets which instilled the farmers to cultivate more stable and non-perishable crops.

\section{Case of Punjab}

In India, future developments led to the realization of the potential of this sector. This paved the way for the green revolution that brought efficient methods of irrigation, protecting crops, and increasing production. To understand this evolution and its future possibilities, Punjab, "The Breadbasket of India", acts as a suitable study area. The farmers of the state shifted from subsistence farming to modern capital-oriented farming. Wheat and Paddy became the focus of new cropping patterns after the green revolution. Currently, $69 \%$ of the net sown area is dedicated to paddy(Baweja, 2017) out of which $73 \%$ is irrigated using bore well.(India, 2017) Similarly, $85 \%$ of the net sown area is used for cultivating wheat. These crops not only yield huge profits at the same time they are highly compatible with each other in terms of season; rice being Kharif and wheat being a rabi crop.

Presently, the conventional crop cycle involves sowing rice in the months of MayJune, a month before other parts of India; to feed the crops with the annual monsoon from June to September. The crop is harvested in October-November making space for sowing wheat which shall be harvested in DecemberJanuary. This pattern also leaves the land with a period where it is provided with time to regain its fertility and nutrient content or a crop that does not exhaust the nutrients of the soil. Growing paddy requires a huge amount of water and its production on large scale exerts undue pressure on natural resources.
Four major rivers flow through the state of Punjab (Sutlej, Ravi, Chenab, and Jhelum). Yet this resource cannot be utilized to its full potential due to the existing administrative conflicts regarding the Indus treaty and conflicts between Rajasthan, Haryana and Central government regarding diversion of river water.(Kumar, 2018) The depletion of these resources put the future of food production in one of the most farming oriented states of India in question.

\section{Evaluating the Existing Scenario}

While studying the future of such a modern capital-oriented farming system, references from the past must also be taken into consideration. The example of 'Gros Michel', an export quality banana that was grown by $80 \%$ of the banana cultivators in Central America and regions around it. In the 1950s a catastrophe struck banana agro-business by the name of Panama disease that brought the species to extinction and the economy of the dependent regions to near collapse. (Ploetz, 2005) This issue was handled by shifting to the second most readily available species i.e. Cavendish. The agro-business was majorly run by big corporations that could sustain a season of crop failure.

A huge part of Punjab is using farmland as an individual asset which is divided among family members when the business is passed on to the next generation, breaking the land parcels into small fragments with time. These small parcels have higher production costs which push 9 out of 10 farmers in Punjab under a debt.(Singh)

\section{Role of Government}

Punjab government is trying its best to protect these farms by providing loan waivers and subsidies but even the government cannot handle a catastrophe of such an extent with the 
existing loan of 95 thousand crores for the upcoming five years as of 2018 (Bharti, At Rs. 1.5 lakh crores, state's debt up $100 \%$ in 4 years, 2018); assuming the administration does not take another loan on its head in that period. The government's way of assisting the farmers was to provide Minimum Support Prices and assured purchase. This further required providing warehouse and storage spaces for the crops. These warehouses were created in a time when most farms in Punjab were becoming capital oriented and shifting to the most profitable crop, i.e. wheat and paddy.

In February 2016, Central Government released the Pradhan Mantri Fasal Bima Yojana that aims to ensure the yields by reducing the pressure of premium on farmers and provide claim at the earliest.(Portal, 2019) As of 2018, Punjab Government rejected its participation in the scheme citing points such as a 10-year benchmark for assessing the normal yield level and proposed to create a scheme of its own. A part of crop produced is also damaged while in storage or market yard which is a loss taken by the state only and is not covered in the scheme. The state also raised the point that the scheme connects the claims to the entire village while the amount is measured by the acres of land owned by an individual farmer. There is no provision of providing a copy to the farmers for the claim for the same reason. Many farmers have already faced such issues where they took a loan to buy livestock that came with mandatory insurance. Since there was no guiding document provided for the farmers mentioning the conditions for a post-mortem that lead to the farmers losing claims for their money (Mohan, 2018).

This scheme leaves the farmers and in turn, the government unsatisfied in terms of securing the benefits of the farmers rather secures the profit-oriented crop pattern that presently contributes to providing the crops to the nation. Currently, Punjab contributes $43.4 \%$ of wheat and $25.5 \%$ of rice to the central food production pool (Punenvis, 201516). The central government must ensure that the nation can produce enough food to sustain the country's food security and produce a surplus to get money in the country via export. This comes in direct conflict with the aims of the state government who is politically and morally obliged to ensure the welfare of the farmers that fall under risk considering the pressure on the resources as the welfare of the farmer is directly linked to the health of his produce.

On the other hand, the state government provides cost-free water for irrigation which is seen as a benefit by the farmers but the final cost, at last, is paid by the consumers and not the government. This system finally ends up as a contributing factor for non-cautious extraction of groundwater without the government paying or being held accountable for the cause of impacts.

Punjab Government has recently proposed to reduce the area under wheat and paddy by about $30 \%$ by shifting around 10 lakh hectares to alternate crops under the "crop adjustment scheme". Even though this proposal is still under consideration, it aims at securing the farmers financially and reducing the pressure on natural resources. It must be realized that even though land (entry 18) and agriculture (entry 14) are both covered in a state subject (GOI, 2019) the crop that must be grown is farmer's choice as long as the practice does not break any other such law or act specifically to the matter. Wheat and paddy still being the most profitable and stable crops growable in the market leave the farmers shifting to other crops vulnerable to the dangers of both market and nature. Even if we assume that the said amount of land is shifted to another type of crop, the replaced crop cannot guarantee more or even equal profit to 
that of the previous pattern. The profit that the farmers did not get due to the shift, in some sense is the cost paid in saving the environmental resources for the rest of the state. Making some people pay for the benefit of others is complete injustice, especially if the people are rather chosen on random. This brings us to the next point, i.e. who shall be accountable for compromising their profit. While the owners of large farmlands are producing wheat and paddy at cheaper prices as per the economy of scales, on the other hand, farmers with small pastures of land will firstly be scattered throughout the state making the provision of infrastructure for the specific crop difficult. Secondly, the smallscale farmers also have a small margin of profit, replacing their crops with low margin vulnerable crops will not only be an injustice but might also lead to civil unrest in regions where it is enacted.

The crops that the farmers are considered to shift are being referred to as vulnerable since the agro-business in Punjab has been oriented majorly towards growing wheat and paddy. The research has also been oriented towards these two crops in order to make them resilient and cheap to produce as compared to other crops that can be grown in the state. It also refers to the fact that most of the farmers have accumulated conventional knowledge and local methods to grow and sell wheat and paddy; a sudden shift might not give the expected outputs or may even lead to crop failure due to the non-judicial use fertilizers, pesticides, insecticides, weedicides, etc. and improper techniques.

The biggest gap left out by the government in this proposal is the specification of the crop that shall replace wheat and paddy. Areas of Punjab have started facing the results of groundwater depletion leading to use of deeper tubes and installing more powerful pumps. All these installations contribute to the production cost and ignoring their upgradation can increase the risks of crop failure. The other alternative is shifting to a more resource convenient crop such as maize or cotton. As of September 2019, the area sown under paddy was 3 lakh hectares less than the usual area according to Sutantar Kumar Airi, the director of agriculture in the state. On the other hand, the area under cotton has increased by 1.4 lakh hectares in the same season. This shift is specifically prominent in the southern districts of Punjab, where the local textile mills and the export market in Pakistan act as the investors into the diversification process. It is estimated that growing cotton can generate a profit of 40-50\% more than paddy crops(Krar, 2019), but the market for cotton is very different from that of paddy or rice. The latter is a food crop and has an available market across India while the dynamics of the cotton market are very different and are not yet controlled by the government and do not have much say in securing farmer's income. The export trade between India and Pakistan is not very dependable and replacing food production for such a market is even riskier.

\section{Impact of Dairy Farming}

The problem gets complicated as one details out the needs and priorities of the administration, market, and environment. In contrast to this problem another pressing issue in terms of food sustainability can be milk production. It is one of the most important parts of the diet. Multiple products such as curd, butter, ghee, beverages, etc. are created from it. Thus, it can be easily said that milk is another component that also needs to be considered when talking about food sustainability. In 2012, the government of Punjab called for "White Revolution", aiming at increasing dairy production and dependency on it as farmers were getting too reliant on wheat and paddy with a minimal margin of profit. Multiple schemes and subsidies were 
provided to promote the livestock market. Milk production has its factors of production; A single cow consumes approximately 150 litres of drinking water, which again puts pressure on the groundwater which is even riskier as too much digging can even bring out water containing lead that may lead to arsenic poisoning in the cattle. It also requires land or sufficient capital to buy fodder daily in dry seasons, infrastructure such as a shed and drinking place, the cow needs to bear a calve to lactate or produce milk which lasts for more than 305 days at least. This means that some amount also needs to be paid to a bull owner to impregnate the cow. The saleable milk produced is the milk left after the calf has been fed. Additional costs are incurred on the immunity and health of the cow and the calf. All these factors contribute to the cost of milk production and are crucial in the process as well. One element that has a highly variable cost and availability is the fodder. We are ignoring the option of reducing production cost by eliminating the calf (a common practice followed in the west) as it is only needed to make the cow lactate and letting it grow is considered as a waste of resources even if it can be sold later; the same cannot be done in India due to the religious and cultural sentiment attached to the cows. Not all livestock owners can own land or grow their fodder and can neither shift to cheaper farm waste as it may risk the health of the livestock. Fodder is becoming expensive every year whereas there has not been any significant increase in the price of milk. (Doshi, 2016) This pushes small scale local livestock owners to dilute the milk to increase their profits, while bigger companies using milk as an ingredient in their main product are shifting to other chemical alternatives.

The cost of the fodder needs to be regularised to sustain milk production and the industries dependent on it. As discussed, there is also a need for creating a crop cycle that helps small scale farmers and reduces pressure on the groundwater. This is a point where livestock and farming can come together to solve the present problem in hand. Since it is cheaper for the large parcel owners to produce wheat and paddy; the farmers with smaller land parcels can be subsidized into producing fodder. The identification of the range of land parcel that shall shift to fodder, cotton or maize production need to be studied in detail on a district level and the availability of market; the policy shall be formulated accordingly rather than a general scheme for the whole state. Shifting back to subsistence farming is a riskier approach and might not be taken positively by the capital-oriented farmers. Since fodder is very cheap to store, there shall be very less capital involved in infrastructure instalment. The demand is also continued throughout the year. The government needs to provide concession on the medicines for the livestock instead of the livestock itself as the market for production and demand is already circulating, it is only when the business is profitable that the production will boom while maintaining the quality of the product. A study showed that a minimum of 7 buffalos needs to be owned by a farmer to assure a profit. (Pal, 2018) A similar study needs to be carried out for different breeds of cows to help farmers know the point where the maximum output can be generated. It is time that the villages also started considering land pooling or community-based livestock raising to maximize profits and distribute them according to the contribution in the initial factors of production.

The food sustainability is not only an aspect of growing and securing crops but also understanding the effects of market dynamics on the crop patterns before they are subjected to any kind of change. At the end of any crop, the pattern is bound to fail in the short term or long term if proper consideration of the 
ecological services and environmental aspects is not taken into consideration. A more detailed approach is required as the market and environment situation are different for different regions of the state and one scheme cannot cover all dimensions, convincing the farmers as well.

\section{References}

Baweja, S. (2017). Groundwater Depletion in Punjab. Encyclopedia of Soil Science, Third(Third).

Bharti, V. (2018). At Rs. 1.5 lakh crores, state's debt up $100 \%$ in 4 years. The Tribune(23rd March).

Bharti, V. (n.d.). The Tribune.

Doshi, V. (2016). Dairy in Distress: the milk revolution draining Punjab dry. The Guardian.

GOI. (2019). Seventh Schedule. Constitution of India.

India, G. o. (2017). Book of Innovations. Government of India.

Krar, P. (2019). Falling groundwater levels driving farmers in Punjab to move away from paddy. The Economic Times.

Kumar, R. (2018). Water Crisis: Issues and Challenges in Punjab. Water Resources Management.

Mohan, V. (2018). Punjab set to roll out its own crop insurance scheme shortly. The Times of India(18th August).

Pal, V. (2018). Economics of Buffalo in Livestock Production System in Punjab: Current Status and Future Prospectus. International Journal of Current Microbiology and Applied Sciences, 7(2319-7706).

Ploetz, R. C. (2005). Panama Disease: An Old Nemesis Rears its Ugly Head.

Portal, P. M. (2019). Pradhan Mantri Fasal Bima Yojna Government Portal. Retrieved November 1st, 2019, from https://pmfby.gov.in/

PUNENVIS. (2015-16). ENVIS. Retrieved November 2019

Singh, K. K. (n.d.). A Pattern of Farmer Suicides in Punjab: Unearthing the Green Revolution.

\section{How to cite this article:}

Nirwan and Prakash Mahto. 2021. Impact of Market, Environment and Governing System on Agriculture and Milk Production in Punjab. Int.J.Curr.Microbiol.App.Sci. 10(07): 343-349. doi: https://doi.org/10.20546/ijcmas.2021.1007.037 